\title{
Varying Feeding Levels and the Growth Response of North African Catfish
}

\author{
Ofonime Edet Afia, Gift Samuel David*, Ini Ubong Umoren
}

Department of Fisheries and Aquatic Environmental Management, University of Uyo, Uyo, P.M.B 1017, Nigeria

\section{*Corresponding Author}

Gift Samuel David

\author{
Article History \\ Received: 07.06.2020 \\ Accepted: 16.06 .2020 \\ Published: 17.06.2020
}

\begin{abstract}
Background: As other animals, fish needs essential nutrients to enable metabolic activities including growth, reproduction, repairs, etc. In fish culture practices, studies on the quantity and rate of feeding are aimed at identifying the optimum level/ration. Objective: This study evaluated growth performance, feed utilization and survival of Clarias gariepinus fingerlings fed varying feeding levels diets in tarpaulin tanks for 14 weeks (August - November, 2019). Methodology: The experiment was carried out at Fulfillment Fish Farm in Uyo Metropolis, Nigeria using 9 tarpaulin tanks of $1 \mathrm{M}^{3}$. Three (3) feeding levels were chosen as treatments with triplicates. These were $2 \%, 4 \%$ and $6 \%$ fresh body weight of the fish and were designated as $2 \mathrm{FL}$, 4FL and 6FL respectively. Twenty-five fingerlings each was randomly stocked in the tanks $\left(25 \mathrm{fish} / \mathrm{m}^{2}\right)$ and starved for 24 hours before the commencement of the feeding trial and the initial mean weight $(3.69 \pm 0.01 \mathrm{~g})$ was measured. The fish was fed twice daily $(08: 00 \mathrm{hrs}$ and 16:00 hrs) at 2\%, $4 \%$ and $6 \%$ respectively with Alaqua feed at $42 \%$ crude protein. The feeding rate was adjusted fortnightly with increase in body weight. Results: Results showed significance $(\mathrm{p}<0.05)$ in mean final weight, mean weight gain, specific growth rate, percentage weight gain, performance index, feed conversion ratio and protein efficiency ratio across the feeding trials with $6 \mathrm{FL}$ having highest growth response and $2 \mathrm{FL}$ having better feed utilization. Survival rate and mortality rate were non significant $(\mathrm{p}>0.05)$ across treatments. Conclusion: On the basis of growth response, feeding African catfish $(C$. gariepinus) at $6 \%$ body weight per day is recommended for raising African catfish at reduced cost of production.
\end{abstract}

Keywords: Clarias gariepinus, African catfish, growth response, feed utilization, feeding level.

\section{INTRODUCTION}

Aquafarming commonly known as aquaculture or fish farming involve culturing aquatic species including fish, aquatic plants, reptiles, amphibians and invertebrates.

Recently, aquaculture have witnessed significant growth, in 2018 alone, world aquaculture output hit 80.03 million tonnes, up from 73.78 million tonnes in 2016 and accounting for 17 to 18 percent of total fish production in Africa [1]. In Africa, a lot has been achieved in fish farming since its introduction. However, when compared to the rest of the world, aquaculture production in Africa is still poor at the global scale, accounting for about $2.48 \%$ of total global aquaculture output 2016 up from $2.32 \%$ in 2014 according to FAO [1] report, whereas, Nigeria accounted for $0.38 \%$ of global aquaculture production in 2016, down from $0.42 \%$ in 2014 [1]. Nigeria's demand for fish and fish products was 3.32 million metric tons, although the domestic fish output realized from aquaculture, artisanal and industrial fisheries in 2014 was 1.123 million metric tonnes in which the fisheries sub-sector contribution was $0.48 \%$ to the Agriculture GDP and contribution of Agriculture to the nation's GDP (2014) was 20.24\% [2].

Feeding level, also called feed ration or feeding rate is the amount of feed provided to cultured fish daily and estimated using the biomass of the fish. The weight of the fish species, along with some environmental factors including water temperature, weather (season), dissolved oxygen, time of the day (photoperiod) and some other water quality materials influences the feed ration given to fish [3]. When measuring fish growth, a number of variables that influences growth response are taking into consideration, these are sufficient feed, access to space, optimal physico-chemical

Copyright @ 2020: This is an open-access article distributed under the terms of the Creative Commons Attribution license which permits unrestricted use, distribution, and reproduction in any medium for non commercial use (NonCommercial, or CC-BY-NC) provided the original author and source are credited. 
properties as well as other environmental factors. "Fish feed forms a major limiting factor for commercial aquaculture as the cost of feed is high and this reduces the profitability in the overall production" [4].

African catfish is the most cultured species in Nigeria since its prominence in the 1970s, although its production is still behind maximum potential owing to heavy reliance on capture fisheries for aquatic products [5]. Nevertheless, aquaculture has been growing since it is now the alternative source for aquatic products and heightened protein demand due to imminent collapse of capture fisheries [6]. Under semi-intensive or intensive form of aquaculture, feeding is paramount as farmers cannot do without it [7], since it contributes more than $60 \%$ of the cost when producing fish in these systems [8].

Studies on Clarias gariepinus nutrition abound, some of these include Aderolu et al. [9], Mustapha et al. [10], Dienye and Olumuji [11], Obe and Omodara [7], Ofor and Afia [4], Umanah and Harry [12], David and Afia [13] and Umanah et al. [14]. The well-being of fish can be impacted by under or overfeeding as a number of poor indices may set in such as pronounced decline in water quality, poor nutrient utilization, reduced biomass and pronounced vulnerability to diseases [15]. The implication is maintaining a balance between maximal use of aquafeed given and enhanced fish growth for aquaculture production to be sustainable, profitable, attractive and fish well-being maintained. This is obtainable when optimal feeding level for rearing Clarias gariepinus is measured.

C. gariepinus is a very important food fish in Sub-Saharan Africa, hence studies to improve its production is vital as it would increase profit for catfish farmers as well as the protein per capita of the populace. Several authors have evaluated different feeding levels in improving growth performance in aquaculture species, some of these studies are $\mathrm{Ng}$ et al. [16], Luo et al. [17], Marimuthu et al. [18], Andem et al. [19], Ashley-Dejo et al. [20], Odedeyi and Ademeso [21], Afia and David [22], and Afia et al. [3].

There is need to maximize feed consumption and reduce feed wastage for the economic success of aquaculture. This is obtainable when suitable feeding level or rate to enhance feed intake, growth response, and survival in aquaculture practices is evaluated. When feed consumption is enhanced, survival is increased, production interval shortened, and feed wastage that causes water quality deterioration is reduced. This study was put forward to ascertain the optimum feeding rate for $C$. gariepinus in tarpaulin tanks. This study aimed at evaluating comparative effect of feeding levels on growth response, feed utilization and survival of African catfish, Clarias gariepinus.

\section{Materials ANd Methods Study area}

The experimental site was Fulfillment Fish Farm at Obio Offot, Abak Road, Uyo Metropolis, Akwa Ibom State. The area lies between Latitude $5.014050^{\circ} \mathrm{N}$, and Longitude $7.877050^{\circ} \mathrm{E}$. The experiment was conducted for fourteen (14) weeks ( $7^{\text {th }}$ August $-6^{\text {th }}$ November, 2019) using 9 tarpaulin tanks of $1 \mathrm{~m}^{3}$.

\section{Experimental fish}

Fingerlings of Clarias gariepinus was purchased from a reputable farm in Uyo Metropolis, Akwa Ibom State, Nigeria. Fingerlings of similar sizes numbering Two Hundred and Fifty were brought to the farm and acclimated for two weeks before the commencement of the feeding trial. The fingerlings used for the experiment were about 3 weeks, 5 days old on arrival to the experimental site and were fed with commercial feed (Coppens $-38 \%$ crude protein).

\section{Experimental design and procedures}

The study took the form of Completely Block Design (CBD). Tarpaulin tanks measuring $1 \times 1 \times 1 \mathrm{M}^{3}$ were used. Each was designed with an outlet for easy drainage and was filled with $0.40 \mathrm{M}^{3}$ of water. Three (3) feeding levels were used as treatments. The treatments were $2 \%, 4 \%$ and $6 \%$ fresh body weight of the fish. Treatments were replicated 3 times. The treatments were designated as $2 \mathrm{FL}, 4 \mathrm{FL}$ and $6 \mathrm{FL}$ for $2 \%, 4 \%$ and $6 \%$ feeding levels respectively. Twenty-five fingerlings each was randomly stocked in the tanks $\left(25 \mathrm{fish} / \mathrm{m}^{2}\right)$ and starved for 24 hours before the commencement of the feeding trial and the initial mean weight $(3.69 \pm 0.01 \mathrm{~g})$ was measured. The fish was fed twice daily (08:00 hrs and 16:00 hrs) at $2 \%, 4 \%$ and $6 \%$ respectively with Alaqua feed at $42 \%$ crude protein. The feed ration was adjusted fortnightly as fish increased in biomass; pellet sizes was also increased monthly. Water was fully exchanged across the tanks biweekly.

\section{Water quality assessment}

Physico-chemical parameters including dissolved oxygen, temperature and $\mathrm{pH}$ were measured weekly (07:00am on Saturdays). Dissolved oxygen and temperature was measured using DO meter (HI 9461) in $\mathrm{mg} / \mathrm{l}$ and ${ }^{\circ} \mathrm{C}$ units respectively while $\mathrm{pH}$ was measured using a pen type $\mathrm{pH}$ meter $(\mathrm{pH}-009$ 111). 


\section{Growth data collection}

Sampling of fish was done fortnightly by draining whole water from all tarpaulin tanks. Fingerlings from each tank were collected with a plastic filter basket and then weighed to nearest $0.01 \mathrm{~g}$ using an electronic weighing balance (TD6002A). Data obtained biweekly was used to determine feed conversion ratio, specific growth rate and mean weight gain. At termination of the experiment, results from weight as well diet data were used to determine growth response parameters such as final mean weight, mean weight gain, percentage mean weight gain, specific growth rate, feed efficiency ratio, protein efficiency ratio, survival rate, mortality rate and performance index, with the formulae below.

\section{Mean weight gain (g) (MWG)}

$$
M W G=M F W-M I W
$$

Where MFW = mean final weight of fish and MIW = mean initial weight of fish

Percentage weight gain (\%) (PWG)

$$
P W G=\frac{M W G \times 100}{M I W}
$$

Where MWG $=$ Mean weight gain of the fish, MIW = Mean initial weight of fish

Specific growth rate (\%/day) (SGR) [3]

$$
S G R=\frac{100 \times[\text { In (mean final weight })-\text { In (mean initial weight })]}{\text { Rearing duration in days }}
$$

Where $\operatorname{Ln}=$ Natural logarithm reading $\left(\log _{\mathrm{e}}\right)$

Survival rate $(\%)(\mathrm{SR})$

$$
S R=\frac{100 \times \text { Total number of fingerling that survived }}{\text { Total number of fingerlings stocked }}
$$

Mortality rate (\%) (MR)

$$
M R=\frac{N t_{1}-N t_{2} \times 100}{N t_{1}}
$$

Where $\mathrm{Nt}_{1}=$ Number of fingerlings stocked, $\mathrm{Nt}_{2}=$ Number of fingerlings remaining

Performance/production index (PI) [23]

$$
P I=\frac{S R \times M F W-M I W}{\text { Rearing period in days }}
$$

Where SR = Survival rate, $\mathrm{MFW}=$ Mean final weight, $\mathrm{MIW}=$ Mean initial weight

Feed conversion ratio (FCR) [24]

$$
F C R=\frac{\text { Dry weight of feed given }(g)}{\text { Wet weight gain of fish }(g)}
$$

Protein efficiency ratio (PER) [25]

Where;

$$
P E R=\frac{\text { Wet weight gain by fish }(g)}{\text { protein intake }(g)}
$$

$$
\text { Protein intake }=\frac{\% \text { protein in feed } \times \text { total weight }(g) \text { of diet consumed }}{100}
$$

\section{Statistical Analysis}

Growth parameters, nutrient utilization parameters and water quality parameters were subjected to one-way analysis of variance (ANOVA) at 0.05 probability level to test for significant difference. Duncan Multiple Range Test was used to separate mean differences. Results with $p \leq 0.05$ were considered significantly different [26]. The statistical analysis was done using IBM SPSS (version 20 by IBM Corporation, New York, USA).

\section{RESULTS}

Water quality assessment during the study period

Table 1 show the results of water quality parameters obtained during the study. There was no significance $(\mathrm{p}>0.05)$ in the water quality parameters of the tanks during the study. $\mathrm{pH}$, dissolved oxygen (DO) and water temperature 
were fairly stable among all treatments during the study. Temperature, DO and $\mathrm{pH}$ were however numerically higher in treatment 4FL.

Table-1: Water quality parameters of Clarias gariepinus under different feeding levels

\begin{tabular}{|l|l|l|l|}
\hline Feeding Levels & 2FL & 4FL & 6FL \\
\hline Temperature $\left({ }^{\circ} \mathrm{C}\right)$ & $26.43 \pm 0.28^{\mathrm{a}}$ & $26.47 \pm 0.34^{\mathrm{a}}$ & $26.27 \pm 0.15^{\mathrm{a}}$ \\
\hline $\mathrm{pH}$ & $5.03 \pm 0.12^{\mathrm{a}}$ & $5.70 \pm 0.31^{\mathrm{a}}$ & $5.30 \pm 0.06^{\mathrm{a}}$ \\
\hline Dissolved oxygen $(\mathrm{mg} / \mathrm{L})$ & $4.77 \pm 0.34^{\mathrm{a}}$ & $5.07 \pm 0.09^{\mathrm{a}}$ & $4.90 \pm 0.25^{\mathrm{a}}$ \\
\hline
\end{tabular}

Means with different superscripts along the same row are significantly different (Duncan's test) $p<0.05$

\section{Growth response of $C$. gariepinus under feeding levels $2 \%, 4 \%$ and $6 \%$}

The growth response, survival and feed utilization parameters of $C$. gariepinus fed $2 \%, 4 \%$ and $6 \%$ fresh body weight respectively is seen in Table 2 . Results shows that there was significant difference $(\mathrm{p}<0.05)$ in all growth indices but for survival rate (SR), mortality rate (MR) and mean initial weight (MIW). Results shows 6FL had the best mean final weight (MFW), mean weight gain (MWG), specific growth rate (SGR), percentage weight gain (PWG), performance index (PI), and protein efficiency ratio (PER). 2FL had better feed conversion ratio (FCR). Survival rate (SR) and mortality rate (MR) were best at $2 \mathrm{FL}$ and $6 \mathrm{FL}$.

Table-2: Growth parameters of $C$. gariepinus under different feeding levels

\begin{tabular}{|l|l|l|l|}
\hline Feeding Levels & 2FL & 4FL & 6FL \\
\hline MIW & $3.69 \pm 0^{a}$ & $3.68 \pm 0^{a}$ & $3.69 \pm 0.01^{a}$ \\
\hline MFW & $163.86 \pm 8.23^{\mathrm{b}}$ & $200.13 \pm 8.78^{\mathrm{b}}$ & $321.18 \pm 28.79^{\mathrm{a}}$ \\
\hline MWG & $160.17 \pm 8.23^{\mathrm{b}}$ & $196.45 \pm 8.78^{\mathrm{b}}$ & $317.49 \pm 28.79^{\mathrm{a}}$ \\
\hline SGR & $3.87 \pm 0.05^{\mathrm{b}}$ & $4.08 \pm 0.04^{\mathrm{b}}$ & $4.55 \pm 0.09^{\mathrm{a}}$ \\
\hline PWG & $4340.56 \pm 224.06^{\mathrm{b}}$ & $5338.23 \pm 238.55^{\mathrm{b}}$ & $8598.91 \pm 794.72^{\mathrm{a}}$ \\
\hline PI & $132.18 \pm 3.12^{\mathrm{b}}$ & $159.54 \pm 2.13^{\mathrm{b}}$ & $260.92 \pm 13.24^{\mathrm{a}}$ \\
\hline SR & $81.33 \pm 4.81^{\mathrm{a}}$ & $80.00 \pm 4.62^{\mathrm{a}}$ & $81.33 \pm 5.33^{\mathrm{a}}$ \\
\hline MR & $18.67 \pm 4.80^{\mathrm{a}}$ & $20.00 \pm 4.62^{\mathrm{a}}$ & $18.67 \pm 5.33^{\mathrm{a}}$ \\
\hline FCR & $0.85 \pm 0.02^{\mathrm{c}}$ & $1.92 \pm 0.04^{\mathrm{b}}$ & $2.74 \pm 0.07^{\mathrm{a}}$ \\
\hline PER & $0.36 \pm 0.01^{\mathrm{c}}$ & $0.81 \pm 0.01^{\mathrm{b}}$ & $1.15 \pm 0.03^{\mathrm{a}}$ \\
\hline
\end{tabular}

Means with different superscripts along the same row are significantly different (Duncan's test) $p<0.05$

\section{DiscusSION}

Due to the prevalent expensiveness of aquafeed in Nigeria and Sub-Sahara Africa, feeding fish has always been challenging to farmers, this equally contributes in making aquaculture production unsustainable and an unattractive venture. The study discovered that Clarias gariepinus adapted to varying feeding levels with no significant impact $(p>0.05)$ on water quality parameters. However, there was significant difference $(p<0.05)$ in major growth indices including mean final weight (MFW), mean weight gain (MWG), percentage mean weight gain (PWG), specific growth rate (SGR), performance index (PI), feed conversion ratio (FCR) and protein efficiency ratio (PER) and no significance $(\mathrm{p}>0.05)$ in survival rate (SR), mortality rate (MR) and mean initial weight (MIW) across the feeding trials. Results from the growth performance and water quality also indicated that fish fed the feeding trials were optimally fed. According to Dwyer et al. [27], "both over-feeding and under-feeding may also affect the specific growth rates and the efficiency of feed conversion". $\mathrm{Ng}$ et al. [16] also noted that water quality may be influenced when fish are overfed, since attributes such as low dissolved oxygen levels, increased biological oxygen demand, and increased bacterial loads will be evident.

Environmental parameters contribute greatly in sustaining a healthy aquatic environment and production of natural food organisms [28]. The physico-chemical parameters of water used for culture of C. gariepinus during the experimental period were within the range recommended for African catfish culture [29, 13] as the water quality parameters in the present study were not affected by the feeding levels. All parameters measured did not differ significantly $(\mathrm{p}>0.05)$. Temperature was within acceptable range for aquaculture $<40{ }^{\circ} \mathrm{C}[30]$. Warm water aquaculture species perform better at temperature range of $25-32{ }^{\circ} \mathrm{C}$. In addition, it is a handicapped situation trying to influence temperature in outdoor installations such as tarpaulin tanks as different species requires varying range of temperature that is optimum for growth and feeding [31]. The range of temperature $\left(26.27-26.43{ }^{\circ} \mathrm{C}\right)$ is similar to the reports of [3,1821]. Dissolved oxygen (DO) is necessary for the energy metabolism of all aerobic aquatic organisms. Cultured fish would die if exposed for long period to less than $0.3 \mathrm{mg} / \mathrm{l} \mathrm{DO}$ [32]. They also stated that $1.0 \mathrm{mg} / 1 \mathrm{DO}$ was the minimum concentration necessary to support fish at least for long period and concentrations below $5.0 \mathrm{mg} / \mathrm{l}$ were undesirable in fish pond. Fluctuation in dissolved oxygen concentration affect fish. The range of DO (5.03 to $5.70 \mathrm{mg} / \mathrm{L}) \mathrm{was}$ within acceptable range for the survival of catfish and tallies with findings of [3, 21-22]. DO values were slightly higher than 
reports of 18-19 and lower than findings of [20]. Differences could be attributed to the bi-weekly water exchange in treatment tanks for the current study. Ekubo and Abowei [32] stated that $\mathrm{pH}$ of 7.0 to 8.5 is ideal for biological productivity as fish become stressed in water with $\mathrm{pH}$ ranging from 4.0 to 6.5 and 9.0 to 11.0 . $\mathrm{pH}$ values were within tolerable range. $\mathrm{pH}$ result $(5.03-5.70)$ is in consonance with reports of 21 and slightly lower than reports of [3, 18-20, 22].

Growth indices, survival and mortality rates aids the evaluation of feed influence and its value composition on fish species [10]. As other animals, fish requires essential nutrients to activate metabolic activities including growth, reproduction, repairs, etc. In fish culture practices, studies on the quantity and rate of feeding are aimed at identifying the optimum level/ration. Increased feed digestibility and increased water quality are the benefits of using the best feeding level [20]. Previous studies on other fish species showed that feed consumption and growth generally increased with feeding level up to a given limit [3,20]. These findings were reported by $\mathrm{Ng}$ et al. [16], at $2.5 \%$ body weight for Mystus numerus fingerlings, Andem et al. [19], at 8.0\% for Clarias gariepinus fingerlings, Ashley-dejo et al. 20, at 5.0\% body weight for $C$. gariepinus fingerlings and Odedeyi and Ademeso [21], at 5.0\% body weight for C. gariepinus broodstock, and Afia et al. [3], at $1.5 \%$ for hybrid catfish. The present study disagrees with the above findings since growth indices increased as feeding level increased up to $6 \%$ feeding level (6FL). Differences may be attributed to species, length of study, culture medium and age differences from the previous studies. This is evidence because at week 12 of the study, mean weight gain decreased abruptly at higher feeding levels (4FL and 6FL) while 2FL continued to increase till end of the study. Mean weight increasing throughout the rearing period for $C$. gariepinus fed varying feeding levels indicate the fish converted the feed to flesh.

In this study, $C$. gariepinus responded positively to varying feeding levels (2FL, 4FL, and 6FL) as showed in their growth response parameters - MFW, MWG, SGR, PWG, PI, FCR and PER. Growth indices from the present study showed that MFW, MWG, SGR, PWG, PI of Clarias gariepinus were comparatively better at 6FL followed by $4 \mathrm{FL}$ before 2FL $(\mathrm{p}<0.05)$. Previous studies including [3,16-21] supports the current study as they highlighted better growth performances as feeding level increased. MWG was higher in this study than findings of [18, 20] and less than that highlighted by $[3,19,21]$. SGR values in the present study was similar to findings of [19] but superior than reports of [3, 16, 20-21] and lower than values of [18]. The differences in numerical values of MFW, MWG, and SGR from previous studies was due to differences in species, length of culture, age of fish, culture medium, stocking density and dissimilar feeding levels.

In fish nutritional studies, the amount of feed consumed is vital for measuring feed conversion ratio (FCR) [33]. FCR is hence an important tool for evaluating the wise use use of feed considering the high cost of aquafeed [3]. The proper understanding of FCR help the farmer to feed the fish to satiation, and when fish are fed exactly the quantity of feed required, they are not stressed and they provide high quality meat for human consumption [34]. In order to maximize profit, FCR should never go above 2 for commercial culture. Results from the present study indicated significant difference $(\mathrm{p}<0.05)$ in FCR for African catfish fed 2FL, 4FL and 6FL with best FCR observed for fish fed 2FL. FCR for 6FL was above recommended limit of 2 which is not profitable for commercial culture. This is further seen in Figure 4, at week 10 when catfish was 14 weeks old, FCR was increasing above 2 in 4FL and 6FL. The increase in biweekly feed conversion ratio also implies that $C$. gariepinus utilized the feed for growth; this is true because FCR increases as the fish increases with age and size [35]. However, best PER was observed in catfish fed 6FL ( $p<0.05)$. The differences in numerical values of FCR and PER from previous studies was due to differences in length of study, age of fish, stocking density and different feeding levels.

Survival rate was non-significant ( $p>0.05)$ across the feeding levels. "Survival has never been a main fear in the culture of $C$. gariepinus because of its resistance to water quality stress as well as diseases" [36]. Likewise, survival rate was not a major concern in the present study because water quality parameters were optimum for $C$. gariepinus survival in the tank. The water quality parameters in the nine (9) tanks were within the tolerable limits for the culture of the species. Survival was better in the present study than reports of $[3,19,21]$ and slightly lower than findings of [18, 20].

\section{CONCLUSION}

The present study has shown varying feeding level influences growth response and feed utilization in Clarias gariepinus fingerlings. Feeding levels revealed significant effect $(\mathrm{p}<0.05)$ on several growth performance indices including MFW, MWG, PWG, SGR and PI. There was no significance (p>0.05) in MIW, SR and MR in catfish fed 2FL, 4FL and 6FL. Both growth rate and feed utilization improved with the increase in the feeding levels up to 6FL but for FCR. Best growth performance was observed in catfish fed 6FL while better feed utilization was observed in fish fed 2FL. On the basis of growth response and nutrient utilization data obtained, feeding African catfish (C. gariepinus) fingerlings at $6 \%$ body weight per day is recommended for raising African catfish at reduced cost of production. The study suggests further studies be carried out at lengthy period, say 12 months to ascertain at what age does growth starts decreasing at a particular feeding level. This can serve as an effective tool for comparing the growth response. 
The study supports previous findings of feeding Clarias gariepinus fingerlings $>5 \%$ body to achieve optimum growth. It is obvious that feeding level is one of the main limiting factors for growth of fishes. This research discovered that, at a certain point (post-juvenile stage) employing higher feeding levels (4FL and 6FL) produced lower mean weight gain and poorer feed conversion ratio, while 2FL produced similar growth response. Hence, feeding level should be reduced at post-juvenile stage to lower cost of feeding catfish and increasing profit. Fish culturists must understand the relationship between growth response and feeding level of this fish. The study is helpful to fish farmers as they can culture Africa catfish in lower feeding level at post-juvenile age with accompanying better growth response and feed utilization. This study will also serve as a useful information for future studies on feeding level and growth performance of Clarias gariepinus.

\section{REFERENCES}

1. Food and Agriculture Organization (FAO). (2018). The state of world fisheries and aquaculture 2016 - Meeting the sustainable development goals. Rome: FAO Fisheries Department Retrieved August 16, 2019 from http://www.fao.org/3/i9540en/i9540en.pdf

2. FCWCFish. (2016). Nigeria fishery statistics - 2016 summary report. Retrieved August 16, 2019 from https://www.fcwc-fish.org/fisheries/statistics/nigeria/901-nigeria-fishery-statistics-2016-summary-report

3. Afia, O. E., David, G. S., \& Udo, I. U. (2019). Studies on the effect of feeding levels on growth response and nutrient utilization of Heteroclarias (hybrid catfish). Journal of Applied Sciences, 19, 723-730.

4. Ofor, C. O., \& Afia, O. E. (2015). Effect of stocking densities on growth and feed utilization of hybrid catfish (Clarias gariepinus x Heterobranchus longifilis) fed at $1 \%$ body weight. American Journal of Biology and Life Sciences, 3(6), 211-217.

5. Yakubu, A. F., Nwogu, N. A., Olaji, E. D., \& Adams, T. E. (2015). Impact of three-different commercial feed on the growth and survival of Clarias gariepinus Burchell, 1822 fry in aquaria glass tanks. American Journal of Experimental Agriculture, 9(1), 1-6.

6. Mwanja, W. W., Akol, A., Abubaker, L., Mwanja, M., Msuku, B. S. and Bugenyi, F. (2006). Status and impact of rural aquaculture practice on the Lake Victoria basin wetlands. African Journal of Ecology, 45, 165-174.

7. Obe, B. W., \& Omodara, G. K. (2014). Effect of feeding frequency on the growth and feed utilization of catfish hybrid (Heterobranchus bidorsalis x Clarias gariepinus) fingerlings. Journal of Agriculture and Environmental Sciences, 3(3), 9-16.

8. Fagbenro, O. A., Nwanna, L. C., Adepanusi, E. O., Adebayo, O. T., \& Fapohunda, O. O. (2005). An overview of animal feed industry and dietary substitution of feedstuffs for farmed fish in Nigeria, 91-107. In: Dris, R. (Ed.), Crops: growth, quality and biotechnology (current status and future prospects). WFL Publisher, Helsinki, Finland.

9. Aderolu, A. Z., Seriki, B. M., Apatira, A. L. \& Ajaegbo, C. U. (2010). Effects of feeding frequency on growth, feed efficiency and economic viability of rearing African catfish (Clarias gariepinus, Burchell 1822) fingerlings and juveniles. African Journal of Food Science, 4(5), 286 - 290.

10. Mustapha, M. K., Akinware, B. F., Faseyi, C. A., \& Alade, A. A. (2014). Comparative effect of local and foreign commercial feeds on the growth and survival of Clarias gariepinus juveniles. Journal of Fisheries, 2(2), 106-112.

11. Dienye, H. E., \& Olumuji, O. K. (2014). Growth performance and haematological responses of African mud catfish Clarias gariepinus fed dietary levels of Moringa oleifera leaf meal. Net Journal of Agricultural Science, 2(2), 79-88.

12. Umanah, S. I., \& Harry, E. H. (2017). Comparative growth performance of two strains of African sharptooth catfish, Clarias gariepinus (normally Pigmented and Albino) fed commercial catfish diets in collapsible tarpaulin tanks. International Journal of Agricultural Research and Food Production, 1(2), 144-160.

13. David, G. S., \& Afia, O. E. (2017). Growth performance, nutrient utilization and survival of African sharptooth catfish (Clarias gariepinus, Burchell 1822) fingerlings fed locally formulated and commercial pelleted diets reared in tarpaulin tanks. International Journal of Agricultural Research and Food Production, 2(1), 13-38.

14. Umanah, S. I., George, E. M. and David, G. S. (2019). Growth performance and feed utilization of Heterobranchus bidorsalis fed with flamboyant seed meal substituted for wheat offal. Asian Journal of Biological Sciences, 12, 842850.

15. Priestley, S. M., Stevenson, E. S., \& Alexander, L. G. (2006). The influence of feeding frequency on growth and body composition of the common gold fish (Carrassius auratus). Journal of Nutrition, 136, 1979s-1981s.

16. Ng, W., Lu, K. Hashim, R., \& Ali, A. (2000). Effects of feeding rate on growth feed utilization and body composition of a tropical bagrid catfish. Aquaculture International, 8(1), 19-29.

17. Luo, Z., Liu, Y., Mai, K., Tian, L., Tan, X., \& Shi, J. (2006). Effects of feeding levels on growth performance, feed utilization, body composition, and apparent digestibility coefficients of nutrients for Grouper Epinephelus coioides juveniles. Journal of the World Aquaculture Society, 37(1), 37-42.

18. Marimuthu, K., Umah, R., Muralikrishnan, S. Xavier, R., \& Kathiresan, S. (2011). Effect of different feed application rate on growth, survival and cannibalism of African catfish, Clarias gariepinus fingerlings. Emir. J. Food Agric, 23(4), 330-337. 
19. Andem, A. B., Ekpo, P. B., Etta, S. E., Udoh, A. G., \& Eyo, V.O. (2013). Effect of different feed application rates on growth performance and body composition of African catfish, Clarias gariepinus fingerlings. International Journal of Scientific Research and Management, 1(9), 471-475.

20. Ashley-dejo, S. S., Olaoye, O. J., Adelaja, O. A., \& Abdulraheem, I. (2014). Effects of feeding levels on growth performance feed utilization and body composition of African catfish (Clarias gariepinus, Burchell 1822). International Journal of Biology and Biological Sciences, 3(2), 12-16.

21. Odedeyi, D., \& Ademeso, A. (2015). Reproductive performance, growth and economic evaluation of Clarias gariepinus broodstocks at different feeding levels. European Journal of Academic Essays, 2(2), 21-27.

22. Afia, O. E., \& David, G. S. (2019). Haematology of hybrid catfish (Heteroclarias): Effect of stocking densities and feeding levels. Trends in Applied Sciences Research, 14, 271-277.

23. Mohanty, R. K. (2004). Density-dependent growth performance of Indian major carps in rain water reservoirs. Journal of Applied Ichthyology, 20, 123-127.

24. Hepher, B. (1988). Nutrition of pond fishes. Cambridge: Cambridge University Press.

25. Wilson, R. P., \& Halver, J. E. (1986). Amino acid and protein requirement of fish. Annual Reviews in Nutrion, 6 , 225-244.

26. Zar, J. H. (2010). Biostatistical analysis. $5^{\text {th }}$ ed. Prentice Hall Inc., New Jersey, USA. 960pp.

27. Dwyer, K. S., Brown, J. A., Parrish, C., \& Lall, S. A. (2002). Feeding frequency affects food consumption, feeding pattern and growth of juvenile Yellowtail Flounder (Limanda ferruginea). Aquaculture, 213(1-4), $279-292$.

28. Haque, M.M., N.T. Narejo, M.A. Salam, S.M. Rahmatullah., \& M.A. Islam. (2003). Determination of optimum stocking density of Macrobrachium rosenbergii in carp polyculture in earthen pond. Pakistan Journal of Biological Science, 6, 898-901.

29. Olurin, K. B., Olojo, A. A., \& Olukoya, O. A. (2006). Growth of African catfish Clarias gariepinus fingerlings, fed different levels of cassava. World Journal of Zoology, 1(1), 54-56.

30. American Public Health Association (APHA). (1998). Standard Methods for the Examination of Water and Wastewater, $20^{\text {th }}$ edn., Washington DC: American Public Health Association.

31. Afia, O., \& David, G. (2017). Growth performance of African in lime treated ponds. Mauritius: Lambert Academic Publishing. 73pp.

32. Ekubo, A.A., \& J.F.N. Abowei, 2011. Review of some water quality management principles in culture fisheries. Research Journal of Applied Science, Engineering and Technology, 3, 1342-1357.

33. Ekanem, A.P., V.O. Eyo, A.I. Obiekezie, U.I. Enin., \& P.J. Udo, 2012. A comparative study of the growth performance and food utilization of the African catfish (Clarias gariepinus) fed Unical Aqua feed and Coppens commercial feed. Journal of Marine Biology and Oceanography, 1(2), 1-6.

34. Shabir, S., Salim M., \& M. Rashid. (2003). Study on the feed conversion ratio (FCR) in major carp, Cirrhinus mrigala fed on sunflower meal, wheat bran and maize gluten. Pakistan Journal of Veterinary Journal, 23, 1-3.

35. Craig, S., \& Helfrich, I. A. (2009). Understanding fish nutrition, feeds and feeding. Virginia Cooperative Extension Publication. Retrieved December 2, 2019 from http://pubs.ext.vt.edu/420/420-256/420-256.html

36. Ngugi, C. C., Boit, C., Bowman, J., Oyoo-Okoth, E., Rasowo, J., Bundi, J. M., \& Cherop, L. (2011). Growth performance, survival, feed utilization and nutrient utilization of African catfish (Clarias gariepinus) larvae co-fed Artemia and a micro-diet containing freshwater atyid shrimp (Caridina nilotica) during weaning. Aquaculture Nutrition, 17(2), 82-89. 